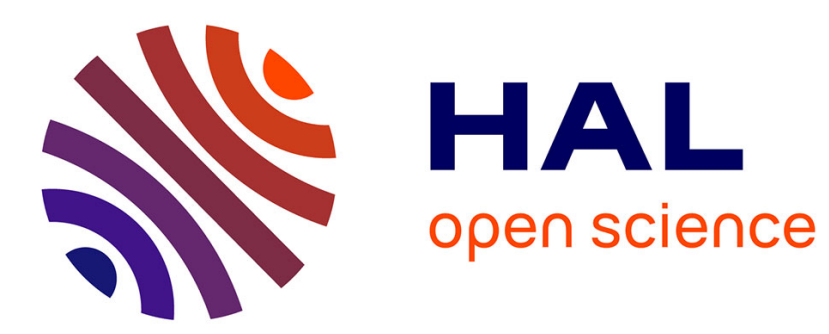

\title{
Effect of polyols on fungal alpha-amylase thermostability
}

Marianne Graber, Didier Combes

\section{To cite this version:}

Marianne Graber, Didier Combes. Effect of polyols on fungal alpha-amylase thermostability. Enzyme and Microbial Technology, 1989, 11 (10), pp.673-677. 10.1016/0141-0229(89)90007-0 . hal-01452224

\section{HAL Id: hal-01452224 \\ https://hal.science/hal-01452224}

Submitted on 18 Jan 2018

HAL is a multi-disciplinary open access archive for the deposit and dissemination of scientific research documents, whether they are published or not. The documents may come from teaching and research institutions in France or abroad, or from public or private research centers.
L'archive ouverte pluridisciplinaire HAL, est destinée au dépôt et à la diffusion de documents scientifiques de niveau recherche, publiés ou non, émanant des établissements d'enseignement et de recherche français ou étrangers, des laboratoires publics ou privés. 


\title{
Effect of polyols on fungal alpha-amylase thermostability
}

\author{
M. Graber and D. Combes
}

Département de Génie Biochimique et Alimentaire, UA-CNRS-544, Institut National des Sciences Appliquées, Avenue de Rangueil, 31077 Toulouse Cedex, France

\begin{abstract}
The influence of different polyols (ethylene glycol, glycerol, erythritol, xylito/, and sorbitol) on the thermostability of funga/ alpha-amylase at $60^{\circ} \mathrm{C}$ has been studied. The results obtained show a stabilizing effect in the presence of polyo/s. In the case of $4 \mathrm{M}$ sorbito/ solution, the enzyme half-life is 2000 -fold longer than in pure water. These polyols have been found as competitive inhibitors for alpha-amylase and their stabilizing efffect has been correlated to their affinity constant except for sorbitol. The influence of two polyol isomers (arabitol and mannitol) on activity and stability of alpha-amylase has a/so been investigated.
\end{abstract}

Keywords: Alpha-amylase; polyol; thermostability; enzyme inhibitor

\section{Introduction}

Fungal alpha-amylase from Aspergillus oryzae is employed in the baking industry as a flour supplement to break down part of the starch into dextrins and fermentable sugars which serve as a substrate for the Bakers' yeast. In order to understand alpha-amylase behavior in industrial media (concentrated starch solutions), the thermostability of a commercial preparation of fungal alphaamylase (Fungamyl from Novo) has been studied in the presence of high levels of polyhydroxylic molecules. These additives, which interact with water molecules for their hydration, are also known to modify the stability of enzymes.I Moreover, they have been chosen from other stabilizing agents because of their similarity of chemical composition (hydroxyl groups) with glucose, which is the only component of starch. Stabilization of enzymes by polyols has been extensively described. For example, Gerlsma z showed that aqueous solutions of polyhydric alcohols protected the native conformation of ribonuclease against thermodenaturation. Back et al. 3 found the same stabilizing effect of polyols against thermal denaturation of various proteins. Moreover, Fujita et al. and Gekko 5 obtained an increase of the thermal denaturation temperature of lysozyme by the use of polyols. In these studies the influence of polyols on protein stability has been explained by their effect on the water structure. These changes in water-water molecule interactions modify the strength of the hydrophobic interactions between the nonpolar groups of the protein. Meanwhile, if these 
phenomena have been extensively studied, no general mechanism of action of these additives has been established. 6'7 Choosing residual activity of enzyme instead of conformational changes of protein 2-5 as a criterion for enzyme stability, the effect of polyols on invertase, 8 Rulactine, a protease from Micrococcus caseolyticus 9 or glucose oxidase $\sim^{\circ}$ thermostability has been investigated. From the results obtained, the authors proposed a more general mechanism for enzyme stabilization taking into account the interactions between enzyme, solvent, and additives.II Such an explanation has also been proposed by Gray. 2 The study of fungal alphaamylase thermostability in the presence of polyols will allow us to better understand such a mechanism.

\section{Materials and methods}

\section{Enzyme}

A commercial liquid fungal alpha-amylase preparation obtained from Novo Industri (Fungamyl $800 \mathrm{~L}$ from Aspergillus oryzae) is used without further purification. Enzyme specific activity is 800 FAU g-1 (FAU = fungal amylase unit, the amount of enzyme that breaks down $5.26 \mathrm{~g}$ of starch per hour at $37^{\circ} \mathrm{C}$ and $\mathrm{pH}$ 4.7). Protein concentration of the preparation is $225 \mathrm{~g} \mathrm{I}-1$ (Bradford, using alpha-amylase from Aspergillus oryzae type X-A from Sigma R as a standard).

\section{Assay of residual amylolytic activity during thermodenaturation}

After addition of $10 / x l$ alpha-amylase preparation diluted 100 times to a maltodextrins solution in 0 . $1 \mathrm{M}$ acetate buffer, $\mathrm{pH} 4.7(2 \mathrm{ml})$ at $37^{\circ} \mathrm{C}$, the variation in concentration of reducing sugars is measured by the 3,5-dinitrosalicylic method as a function of time, using D-maltose as a standard. Maltodextrins (Glucidex 6 from Roquette) are used after ultrafiltration with a 10,000-dalton cut-off hollow fiber ultrafiltration device (Amicon) to discard oligosaccharides. One unit of alpha-amylase activity corresponds to the amount of enzyme that liberates $1 / x m o l$ of reducing sugars (maltose equivalent) per minute under the conditions of assay. The effect of maltodextrin concentration on alpha-amylase activity has been studied. The maximal initial reaction rate $(\mathrm{Vmax})$ and the Michaelis constant (KM) have been calculated from these data: $V$ max $=27.45$ $102 \mathrm{U}, \mathrm{Km}=2 \mathrm{gl} \mathrm{I}$.

\section{Study of thermal stability in the presence of polyols}

The differently concentrated solutions of polyols of analytical grade (ethylene glycol, glycerol, erythritol, xylitol, arabitol, sorbitol, and mannitol) are added to the alpha-amylase solution such that the final dilution of the enzyme preparation is I / 100. The water used for these solutions is of MilliQ quality and the value of the apparent $\mathrm{pH}$ of the mixtures as measured by a $\mathrm{pH}$ meter with a glass electrode is between 6 and 7 . This range of $\mathrm{pH}$ corresponds to the optimum for the stability of the enzyme. Each mixture is incubated at $60^{\circ} \mathrm{C}$. At regular intervals of time, the residual amylolytic 
activity is determined as described before. The enzyme half-life is obtained by plotting the logarithmic evolution of the residual enzyme activity (percentage of the original activity) as a function of the incubation time at $60^{\circ} \mathrm{C}$. Thus the time at which $50 \%$ initial activity is reached corresponds to the half-life of the enzyme in the reaction conditions. The determination of the halflife for a reference solution (i.e. an enzyme solution without any additive) is performed in parallel. The results obtained are expressed in the form of protective effect (or stabilizing factor), as defined by the ratio of alpha-amylase half-life in the presence of polyols to the half-life of alpha-amylase without any additive.

\section{Study of inhibition by polyols}

The initial rate of reaction is determined for various synthetic substrate concentrations $[6,12,18,24$ g 1 ] of 4-nitrophenyl-alpha-D-maltoside (Boehringer)] with and without addition of polyol as inhibitor $(0.1,0.2$, and $0.3 \mathrm{M})$. The enzyme reaction is carried out at $\mathrm{pH} 4.7$ in $0.1 \mathrm{M}$ acetate buffer at $30^{\circ} \mathrm{C}$ and followed spectrophotometrically at $400 \mathrm{~nm}$. After preheating 15 rain at $30^{\circ} \mathrm{C}, 150 / \mathrm{xl}$ of alphaamylase preparation diluted 100 times is added and mixed to $750 / \mathrm{xl}$ of substrate solution with or without inhibitor, which is placed in a spectrophotometer tube in the thermostated compartment of the apparatus, and the optical density at $400 \mathrm{~nm}$ is measured for initial 3 rain. The proportionality between the initial rate and the enzyme concentration has been confirmed to hold. Monitoring the effect of 4-nitrophenyl-alpha-D-maltoside concentration on alpha-amylase activity, the following values have been calculated: $V \max =0.2$ units ODmin $\mathrm{J}=5.02 \mathrm{IO2} \mathrm{U}$ and $\mathrm{Km}=71.4 \mathrm{gl}-1$.

\section{Results and discussion}

\section{Effect of polyhydric alcohols on alpha-amylase thermostability}

The protective effect of different additives containing two to six carbon atoms [ethylene glycol (C2), glycerol (C3), erythritol (C4), xylitol (C5), and sorbitol (C6)] has been studied.

Figures 1 and 2 show the evolution of the protective effect of these additives on alpha-amylase, as a function of their concentration. All the polyhydric alcohols have a positive effect on alpha-amylase stability, which increases with their rising concentration. It may be seen from Figure 2 that the protective effect obtained by using a $4 \mathrm{M}$ sorbitol solution is higher than 2000.

In Figure 3 the effect of the length of the polyhydric alcohol molecule on the stabilizing factor is given and related to the number of hydroxyl groups per molecule.

The stabilizing effect increases with the number of hydroxyl groups contained in the molecule, except for xylitol whose protective effect is weaker than that of erythritol at concentrations ranging from 1 to $2.5 \mathrm{M}$.

Previous studies of enzyme thermal denaturation in the presence of polyols have been carried out by 
residual activity measurements. The results obtained with invertase, 8 Rulactine, 9 and glucose oxidase $1^{\circ}$ show that the stabilizing effect of polyols increases with their concentration as for the alpha-amylase. The intensity of the effect is nevertheless much more important for alpha-amylase than for the other enzymes. For instance, in the presence of sorbitol, which has the most important protective effect on both alphaamylase and invertase, the effect is about 40 times greater for alphaamylase. The stability maxima are obtained with a $4 \mathrm{M}$ xylitol solution for glucose oxidase $1^{\circ}$ and $3 \mathrm{M}$ erythritol solution for Rulactine. 9 Their protective effects correspond to 25 and T2, respectively, as the maximum for alpha-amylase is about 2000 in a $4 \mathrm{M}$ sorbitol solution. The effect also reaches 750 in a $3 \mathrm{M}$ sorbitol solution and 100 in a $4 \mathrm{M}$ xylitol solution for alpha-amylase.

Then for different enzymes the intensity of the stabilizing factor of polyols is very changeable and the nature of the most efficient polyol as protective agent varies. Considering these results the stabilizing effect of polyols is not an absolute effect, but it depends on the nature of the enzyme studied and the degree of its interaction with the additive.

In the following study, we aim to obtain further explanation of the stabilizing effect of polyols for alpha-amylase from the investigation of the nature and the strength of the specific interactions between the different additives and alpha-amylase. As sorbitol has been described as a competitive inhibitor for alphaamylase from Aspergillus oryzae, $\mathrm{n} 3$ this molecule can be considered as a substrate analogue which combines with the active site of the enzyme. We have deterdetermined the nature and the degree of inhibition of alpha-amylase activity of the polyols whose protective effect was studied, in order to establish a relation between their stabilizing effect (for alpha-amylase) and their interaction with the active site of the enzyme.

\section{Competitive inhibition of alpha-amylase activity by polyols}

The type of inhibition is determined for all the polyhydric alcohols from [S]/V versus [S] plots (Dixon plot) in the presence of and absence of inhibitors. For each polyol used, the plots of the results obtained in the presence of inhibitor give straight lines parallel to that in the absence of inhibitor. These results agree with a competitive inhibition whose rate equation is written as follows:

$$
\frac{[\mathrm{S}]}{V}=\frac{1}{V_{\max }}[\mathrm{S}]+\frac{K_{\mathrm{m}}}{V_{\max }}\left(1+\frac{[\mathrm{I}]}{K_{\mathrm{i}}}\right)
$$

Figure 4 shows an example of the plot obtained for xylitol. Such results were expected for polyhydric alcohols because of their partly structural similarity to substrate.

The KM values are determined from the point of intersection of I/KM versus [I] plots (Dixon plot) at four substrate concentrations. 
An example for sorbitol as inhibitor is shown in Figure 5. The inhibitor constants (Ki) obtained for the polyhydric alcohols using 4-nitrophenyl-alpha-Dmaltoside as substrate are given in Table 1, as also the $1 / K^{\sim}$ values measuring the affinity of alpha-amylase for the different inhibitors. The $K^{\sim}$ obtained for sorbitol is practically the same as the Ki obtained by Nitta, 3 equal to $4310-z \mathrm{M}$.

Alpha-amylase affinity for polyhydric alcohols increases as the number of hydroxyl groups contained in the molecule rises, except for sorbitol whose $1 / \mathrm{KM}$ value is situated between those of glycerol and erythritol. The relation between the $1 / \mathrm{Ki}$ values and the protective effect against thermal denaturation at $3.5 \mathrm{M}$ polyol concentration is represented on Figure 6. A linear relation for ethylene glycol, glycerol, erythritol, and xylitol is observed. In the case of sorbitol, whose protective effect at 3.5 $\mathrm{M}$ is much more important, it is impossible to obtain such a correlation. A linear relation between the 1/Ki values and the protective effect does not exist at other concentrations than $3.5 \mathrm{M}$. The high concentration at which the relation is observed can be related to the relatively poor alphaamylase affinity for the polyols. These additives have to be at very high concentration to have a marked interaction with the active site of the enzyme. Thisinteraction with the active site of the alphaamylase during thermal denaturation can be considered as one of the factors explaining the stabilizing effect of polyols, but it does not permit us to explain the effect at all concentrations and the remarkable effect of sorbitol.

Such a protective effect of a competitive inhibitor (Benzamidine in the case of trypsin) against thermal denaturation has been described. TM It has been explained by the strong adsorption of the inhibitor on the active site of the enzyme, protecting the protein structure from conformational changes.

In order to confirm the role of interactions of additives with the active site in thermal stabilization, we have studied the protective effect and the inhibition degree of other polyol isomers (mannitol and arabitol) of the polyols previously used. Effect of mannitol and arabitol on alpha-amylase thermostability and activity Mannitol (C6) and arabitol (C5) have also been identified as competitive inhibitors for the alpha-amylase according to the method described before. The Ki values obtained are equal to 31 and $7.510-2 \mathrm{M}$, respectively. The affinity of alpha-amylase is thus more important for mannitol and arabitol than for their isomers sorbitol and xylitol.

Figure 7 shows the comparison between protective effects of arabitol and xylitol and those of mannitol and sorbitol (see inset of Figure 7). The protective effect increases slightly from sorbitol to mannitol up to $1 \mathrm{M}$ (this concentration corresponds to the solubility maximum of mannitol), as the affinity of alphaamylase is slightly greater for mannitol than for sorbitol. (The KM values of mannitol and sorbitol are respectively equal to 31 and $42.510-2 \mathrm{M}$ ). Moreover, the protective effect increases markedly from xylitol to arabitol at all concentrations, as does the affinity of alpha-amylase from xylitol to arabitol (Ki respectively equal to 21 and $7.510-2 \mathrm{M}$ ). 


\section{Conclusion}

The effect of polyols on alpha-amylase stability has been studied. A very important protective effect (more than 2000) has been obtained with a $4 \mathrm{M}$ sorbitol solution. To better understand the action of polyols as stabilizing agents, the interaction between these additives and alpha-amylase has been studied. As polyols have been found to be competitive inhibitors for alpha-amylase, the degree of interaction with the active site of the enzyme has been investigated by the determination of the inhibition constants. A linear relation has been observed between the affinity for the active site of alpha-amylase and the protective effect at high concentration of four polyols but not for sorbitol. This result shows that the interaction of the polyols with the active site of the enzyme is only one of the factors of the enzyme stabilization mechanism.

In the case of polyols the mechanism of enzyme stabilization has been envisaged as composed of different factors, j 'j2 Polyols, as hydroxy compounds, may, via hydrogen bonds, both bind to the enzyme and improve the degree of order of the solvent. These two types of interactions make the protein more rigid and thus more stable.J2 Interactions between enzyme, solvent, and additive molecules must thus be taken into account. This confirms the results obtained with other enzymes. 8- 0 The protective effects of molecules of polyol isomers have been compared. It has been demonstrated that the more important the affinity for the active site of the enzyme, the stronger is the protective effect of the polyol.

Finally, it may thus be assumed that by modifying the biocatalyst microenvironment by the use of polyols, it has been possible to obtain an alpha-amylase preparation with a highly increased resistance to thermodenaturation. From an applied point of view, this classical approach of enzyme stabilization should be kept in mind.

\section{References}

I Wiseman, A. in Topics in Enzyme and Fermentation Biotechnology, Vol. 2 (Wiseman, A., ed) Halsted Press, Chichester, 1978, pp. 280-303

2 Gerlsma, S. Y. J. Biol. Chem. 1968, 243, 957-\%1

3 Back, J. F., Oakenfull, D. and Smith, M. B. Biochemistry 1979, 18, 5191-51\%

4 Fujita, Y., Iwasa, Y. and Noda, Y. Bull. Chem. Soc. Jpn. 1982, 55, 1896-1900

5 Gekko, K. J. Biochem. 1982, 91, i197-1204

6 Klibanov, A. M. Ado. App/. Microbiol. 1983, 29, 1-24

7 Torchilin, V. M. and Martinek, K. Enzyme Microb. Technol. 1979, 1, 74-82

8 Combes, D. and Monsan, P. Ann. NY Acad. Sci. 1984, 434, 61-63

9 Yoovidhya, T., Combes, D. and Monsan, P. Biotechnol. Lett. 1986, 8, 333-338

10 Ye, W. N., Combes, D. and Monsan, P. Enzyme Microb. Technol. 1988, 10, 498-501 
11 Combes, D., Yoovidhya, T., Girbal, E., Willemot, R. M. and Monsan, P. Ann. NYAcad. Sci. 1987, 501, $59-62$

12 Gray, C. J. in World Biotech. Report, Vol. 1, Pinner, UK, Online Publication Ltd., pp. 617-626

13 Nitta, Y., Hiromi, K. and Ono, S. J. Biochem. 1971, 69, 577-588

14 Blanco, R. M. and Guisan, J. M. Enzyme Microb. Technol. 1988, 10, 227-232

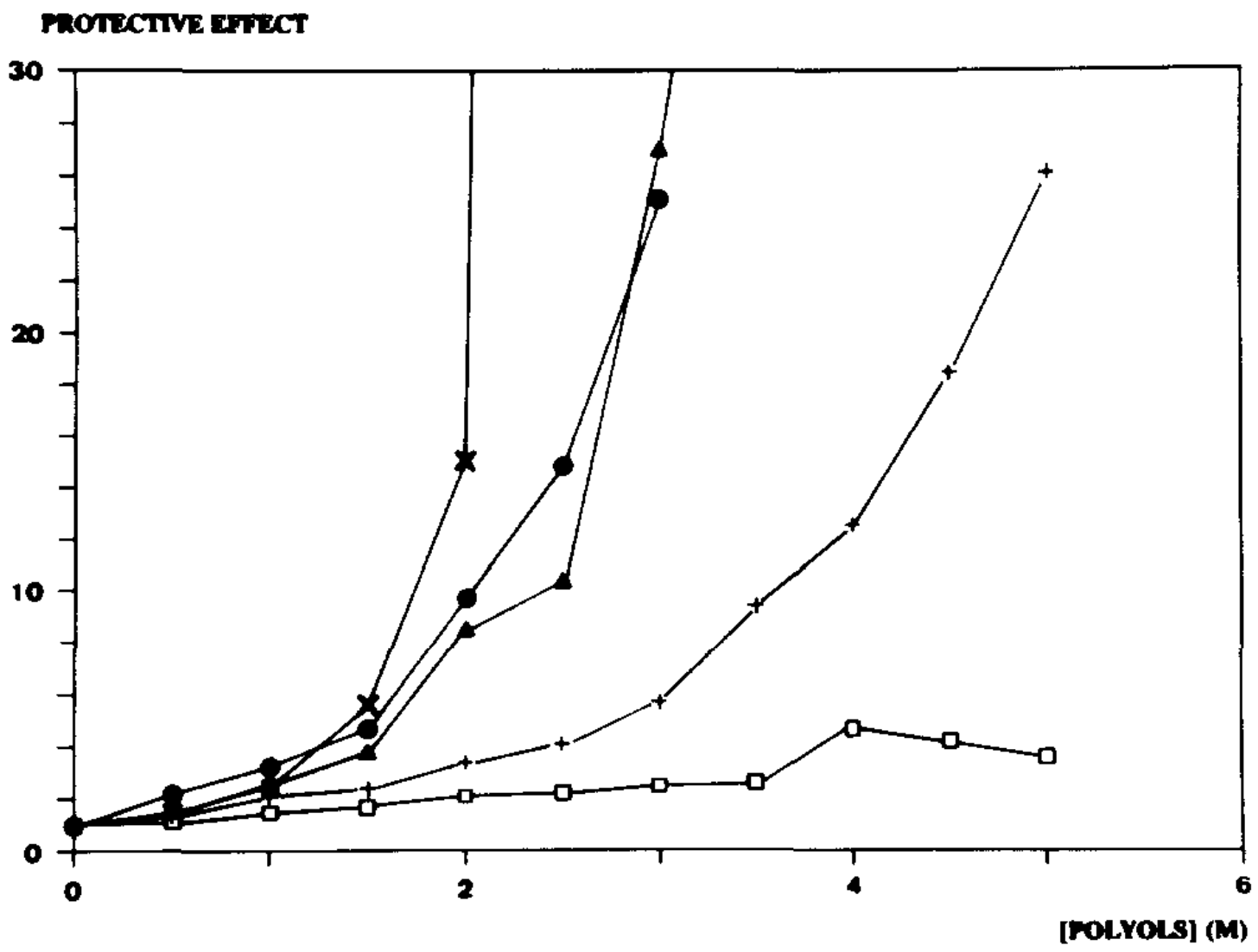

Figure 1 Effect of polyhydric alcohol concentration on alphaamylase stability. Protective effect is defined as the ratio of alpha-amylase half-life with additive to alpha-amylase half-life without additive. Denaturation is performed at $60^{\circ} \mathrm{C}$; residual activity of alpha-amylase is measured at $37^{\circ} \mathrm{C}$ using $50 \mathrm{~g}$ 1-1 maltodextrin solution in $0.1 \mathrm{M}$ acetate buffer, $\mathrm{pH}$ 4.7. (D) Ethylene glycol, (+) glycerol, (0) erythritol, (A) xylitol, $(x)$ sorbitol 


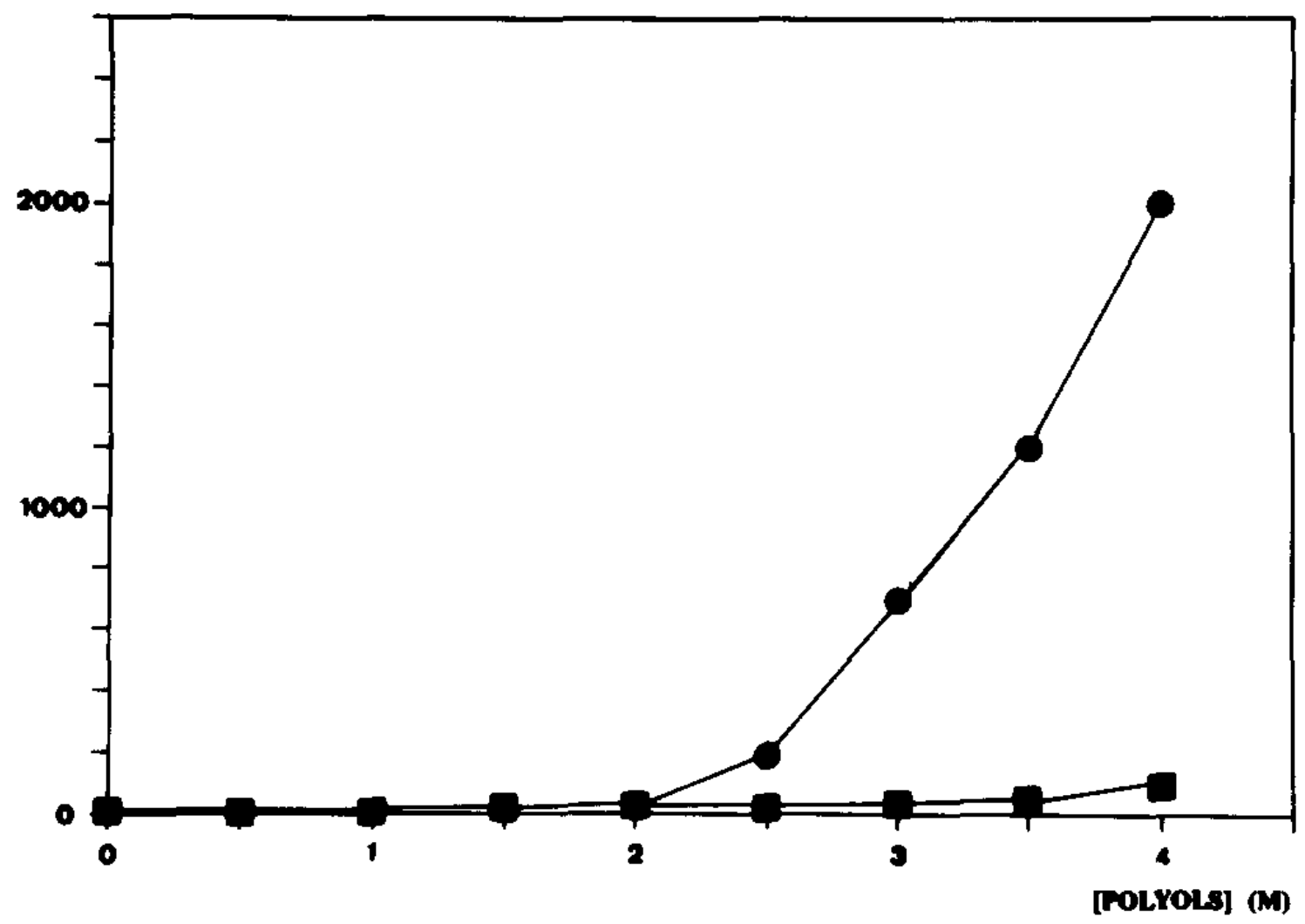

Figure 2 Effect of sorbitol and xylitol concentration on alphaamylase stability. Experimental conditions are as indicated in Figure 1. (II) Xylitol, (O) sorbitol

Figure 3 Effect of length of polyhydric alcohol molecule on protective effect of alpha-amylase. Experimental conditions are as indicated in Figure 1. ( ) $0.5 \mathrm{M},\left(\mathrm{C}^{\prime} 4\right) 1 \mathrm{M},(\mathrm{O}) 1.5 \mathrm{M},(\mathrm{A}) 2 \mathrm{M},(\mathrm{X})$ $2.5 \mathrm{M},(\mathrm{V}) 3 \mathrm{M}$ 


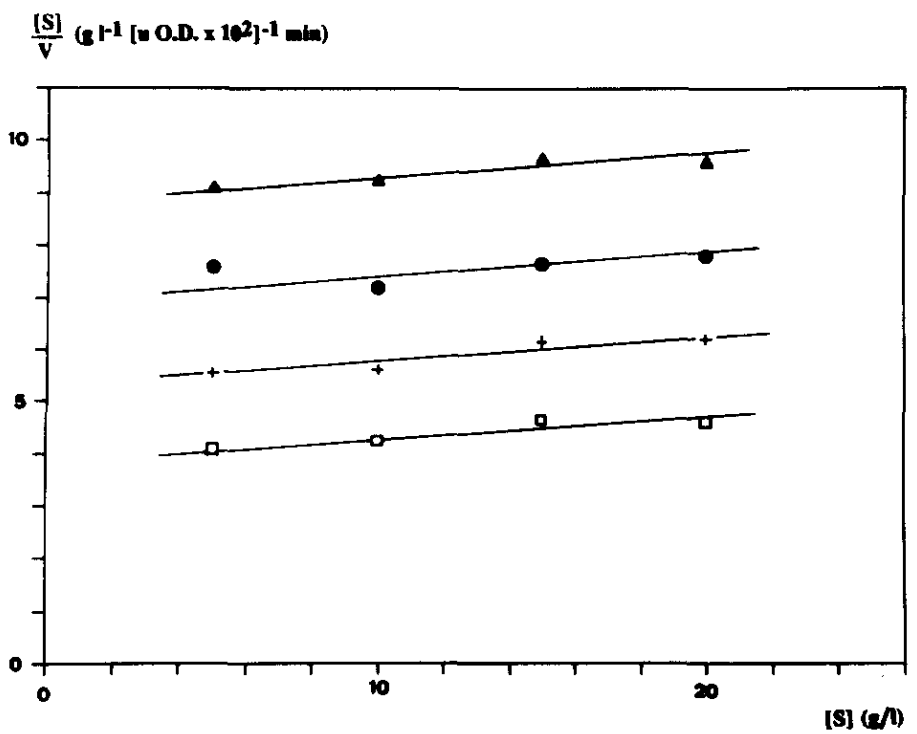

Figure 4 [S]/ $V$ versus [S] plots for competitive inhibition of alpha-amylase activity in the presence of xylitol. Alpha-amylase activity is followed spectrophotometrically at $400 \mathrm{~nm}$ with 4-nitrophenyl-alpha-d-maltoside as substrate $\left(\mathrm{pH} 4.7\right.$ and $\left.30^{\circ} \mathrm{C}\right)$. (G]) $[\mathrm{I}]=0,(+)[I]=0.083 \mathrm{M},(\mathrm{O})[\mathrm{I}]=0.167 \mathrm{~m},(\Delta)[\mathrm{I}]=0.25 \mathrm{M}$

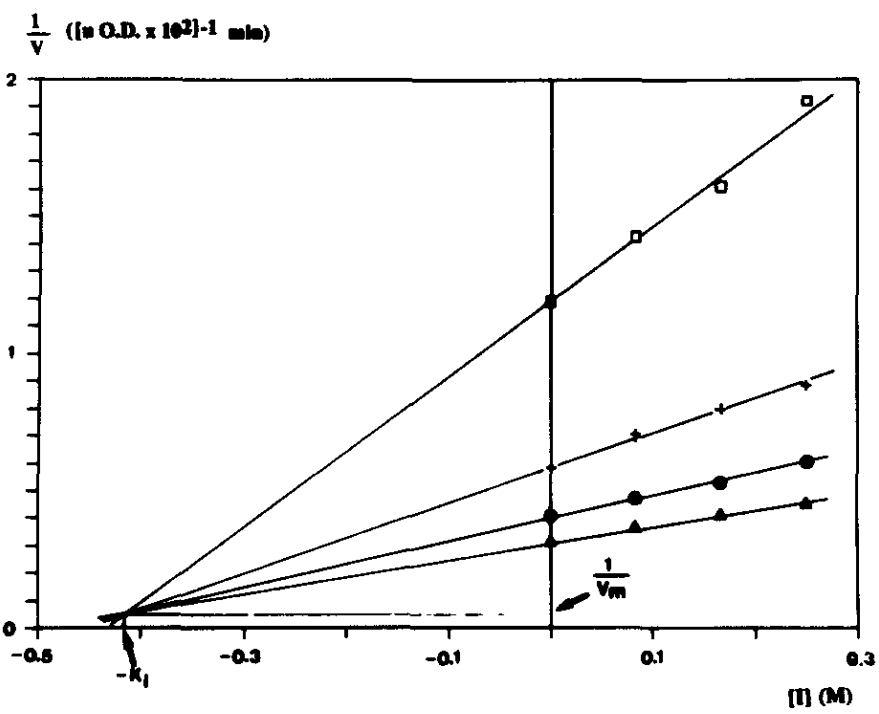

Figure $51 / V$ versus [I] plots for competitive inhibition of alpha-amylase activity in the presence of sorbitol. Experimental conditions are as indicated in Figure 4. (G) $[S]=5 \mathrm{~g} \mathrm{I}^{-1},(+)[S]=$ $10 \mathrm{~g} \mathrm{I}^{-1}, \mathrm{~K} \leftarrow[\mathrm{S}]=15 \mathrm{~g} \mathrm{I}^{-1},(\mathbf{A})[\mathrm{S}]=20 \mathrm{~g} \mathrm{I}^{-1}$ 
Table 1 Values of inhibition constants of ethylene glycol, glycerol, erythritol, xylitol, and sorbitol

\begin{tabular}{lcc}
\hline & $K_{\mathrm{i}}\left(10^{2} \mathrm{M}\right)$ & $1 / K_{\mathrm{i}}\left(\mathrm{M}^{-1}\right)$ \\
\hline Ethylene glycol & 240 & 0.42 \\
Glycerol & 53 & 1.88 \\
Erythritol & 37 & 2.7 \\
Xylitol & 21 & 4.8 \\
Sorbitol & 42.5 & 2.35 \\
\hline
\end{tabular}

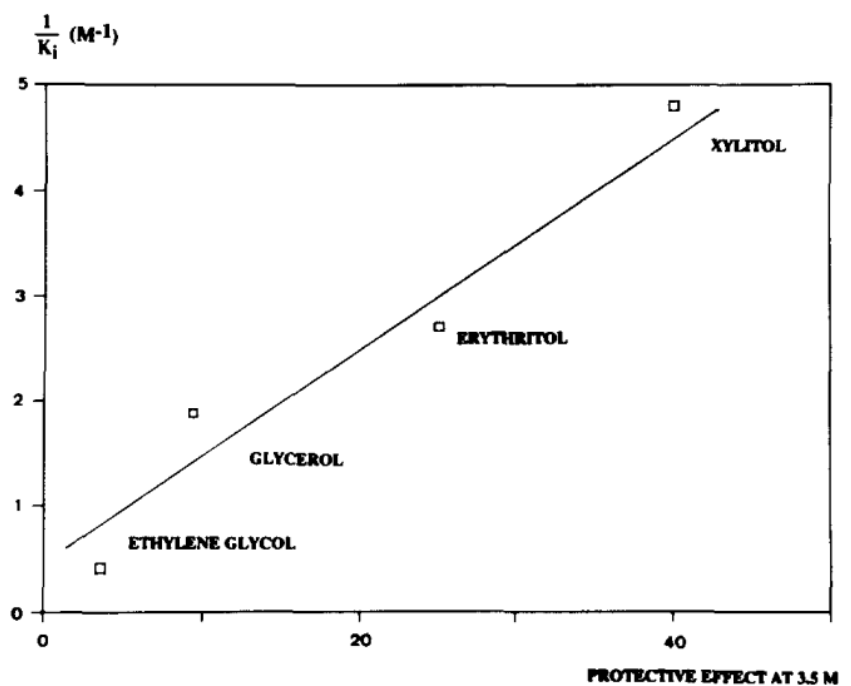

Figure 6 Relation between protective effect at $3.5 \mathrm{M}$ and $1 / K_{\mathrm{i}}$ $\left(\mathrm{m}^{-1}\right)$ values of ethylene glycol, glycerol, erythritol, and xylitol

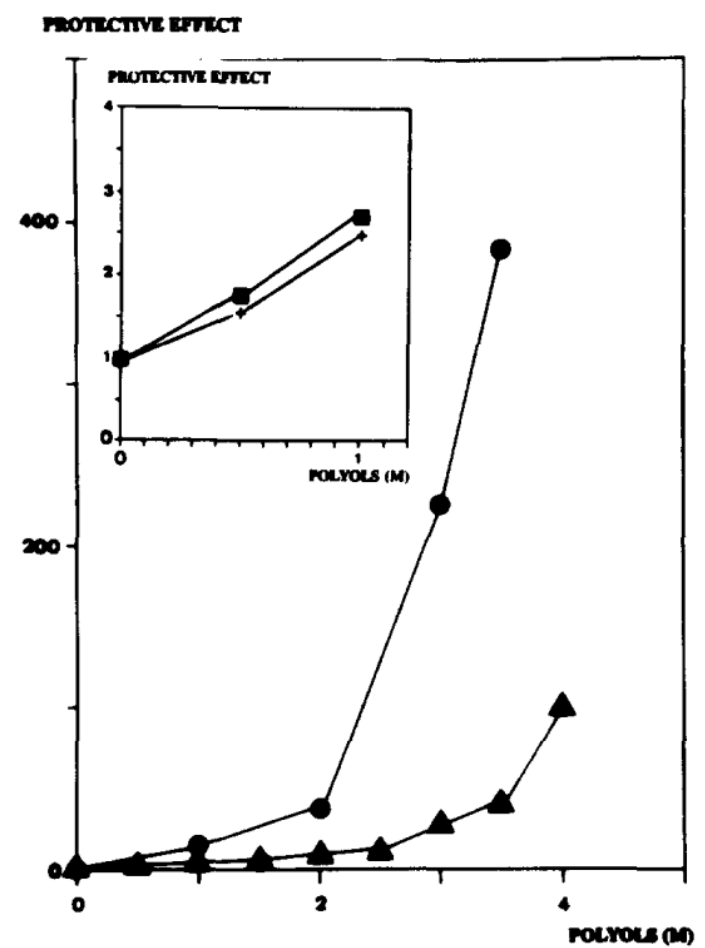

Figure 7 Effect of arabitol and xylitol concentration on alphaamylase stability. Experimental conditions are as indicated in Figure 1. $(\leftarrow$ Arabitol, $(\mathbf{\Delta})$ xylitol. Inset: Effect of mannitol and sorbitol concentration on alpha-amylase stability. Experimental conditions are as indicated in Figure 1. () Mannitol, (+) sorbitol 